\title{
Nutritional status of children 7-36 months old from millet consuming communities of Masindi District, Western Uganda
}

\author{
Barugahara Evyline Isingoma ${ }^{1,2^{*}}$, Samuel Kuria Mbugua ${ }^{1}$ and Edward Gichohi Karuri ${ }^{1}$
}

\begin{abstract}
Background: Several national reports have indicated poor nutritional status among children from Western Uganda where millet porridge is a predominant complementary food. However, little is known about the nutritional status of 7-36 months old children from millet consuming communities of Western Uganda.

Methods: A cross-sectional study was conducted in Bujenje County of Masindi District. A total of 636 children from 23 villages within Bwijanga and Budongo sub counties were randomly selected. Anthropometric measurements of children were taken. Data on demographic and socioeconomic characteristics of children's households, their dietary practices and morbidity patterns was collected using a self-administered questionnaire. A statistical Package for the Social Sciences (SPSS) version 20 and Emergency Nutritional Assessment (ENA) Software Version 2010 were used for analysing data. The relationship between demographic and socioeconomic characteristics of households and children's nutritional status was determined using Chi-square tests. Pearson's correlation coefficient was used to determine the association between children's nutritional status and the amount of millet porridge consumed. A $p$-value of $<0.05$ indicated statistical significance.
\end{abstract}

Results: A proportion of 30.5\% children were stunted, $11.6 \%$ underweight and $7.4 \%$ wasted. Underweight and wasting were significantly high in Budongo sub county at $p=0.044$ and $p=0.005$ respectively. Stunting and underweight were highest between 12 and 23 months at $p=0.005$ and 0.020 respectively. Although millet porridges formed the bulk of children's meals, they could only cater for $<60 \%$ of the recommended daily nutrient intake. Children with diarrhoea were 1.4 and 2 times likely to become stunted and underweight at $p=0.025$ and 0.007 respectively. Feeding practices for children with diarrhoea were contrary to World Health Organisation's recommendations in more than $50 \%$ of the studied children. There was a significant association between Height-for-Age Z scores, Weight-for-Height Z scores and the amount of millet porridge consumed by children ( $r=-0.20, p<0.001$ and $r=0.14, p<0.001$ respectively).

Conclusions: Results showed slightly higher percentages of stunted, underweight and wasted children compared to national figures. This was attributed to high incidences of diarrhoea and inadequate feeding practices especially for children 12-36 months old.

Keywords: Nutritional status, Millet consuming, 7-36 months, Western Uganda

\footnotetext{
* Correspondence: bisingoma@gmail.com

${ }^{1}$ Department of Food Science, Nutrition and Technology, University of

Nairobi, Nairobi, Kenya

2 Department of Human Nutrition and Home Economics, Kyambogo

University, Kampala, Uganda
}

(c) The Author(s). 2019 Open Access This article is distributed under the terms of the Creative Commons Attribution 4.0 International License (http://creativecommons.org/licenses/by/4.0/), which permits unrestricted use, distribution, and reproduction in any medium, provided you give appropriate credit to the original author(s) and the source, provide a link to the Creative Commons license, and indicate if changes were made. The Creative Commons Public Domain Dedication waiver (http://creativecommons.org/publicdomain/zero/1.0/) applies to the data made available in this article, unless otherwise stated. 


\section{Introduction}

Child malnutrition is a public health problem since it is a major contributing factor to mortality, morbidity, intellectual and physical disability among children [1]. The first 3 years of life are the most critical in the development of children due to the high nutrient requirements, limited gastric capacity and low immunity during this period [2]. The consequences of inadequate nutrient intake during this period may result into irreversible damages to the mental and physical development of children [3]. Globally, an estimated 165 million, 10 million and 52 million of children below 5 years are stunted, underweight and wasted respectively [4]. Africa and Asia account for more than $90 \%$ of the world's stunted children, with Sub-Saharan Africa having a prevalence rate of $36 \%$ compared to $56 \%$ for Asia [4]. About $29 \%$ of children less than 5 years in Uganda are stunted, $11 \%$ underweight and $4 \%$ wasted [5]. The Uganda Demographic and Health Survey reports have persistently ranked the Western region of Uganda as a very high prevalence area for child stunting with some districts having a percentage prevalence of above $30 \%$ [5-7].

Masindi District is one of the 5 districts in Bunyoro sub region found in Western Uganda. Recent Demographic and Health Survey reports indicate 34.5\% stunting, 9.1\% underweight and $3.8 \%$ wasting rates among children below 5 years in Bunyoro sub region. Data on the nutritional status of children below 5 years in Masindi District specifically is scanty. However some studies have indicated that $22 \%$ of the children under 5 years were found to be underweight in 2006 [8].

Millet porridge is a common complementary food in Western Uganda [9, 10]. Finger millet (Eleusine coracana) is recommended as a weaning food because it is one of the most antiallergenic, easy to digest and nutritious foods among cereals [11]. However, being plant based, it is limited in essential amino acids, has low energy and nutrient density and a high content of ant nutrients such as phytates and tannins [12]. Its prominent use has been attributed to the existence of high levels of child malnutrition among some communities [13]. Ant nutrients in millet reduce the bioavailability of vitamins and minerals and contribute to poor digestibility of starch and protein and this makes young children relying on it vulnerable to malnutrition $[12,14]$.

A survey carried out in Masindi District found out that inadequate nutrient intake and infections especially diarrhoea and malaria were common among children aged 7-24 months [10]. According to the UNICEF conceptual framework, inadequate dietary intake and diseases in children immediately manifest into poor nutritional status. The current study was aimed at generating information about nutritional status and feeding practices among millet consuming communities. The specific objective of this study was to identify the association between nutritional status and household socio-demographic, morbidity patterns and feeding practices among children 7-36 months old from millet consuming communities in Masindi District.

\section{Methods \\ Study setting}

The study was cross-sectional and analytical. Masindi District was purposively chosen because $53.1 \%$ of children aged 7-24 months consume millet porridge [10], it is also one of the most rural based districts in Western Uganda and it is characterised by low income households and common occurrence of infections among children [8]. Two highest millet producing sub counties in Masindi District namely Budongo and Bwijanga were chosen [8]. Fisher's Equation [15] was used to calculate the sample size: $\mathrm{n}=\mathrm{Z}^{2} \mathrm{pq} / \mathrm{d}^{2}$. Where $\mathrm{n}=$ minimum sample size, $\mathrm{z}=$ the standard normal deviate at 1.96 for a confidence level of $95 \%, \mathrm{p}=$ proportion of stunted children below 5 years in Western Uganda [5], $\mathrm{q}=$ the proportion of children below 5 years who are not stunted in Western Uganda, $\mathrm{d}=$ the degree of accuracy desired, set at 0.05 . The study subjects and respondents were children aged 7-36 months and their mothers/caretakers respectively. A sample size of 636 households was recruited by random cluster sampling method. Children aged 7-36 months were recruited from 23 villages $(n=10$ in Budongo and $n=13$ in Bwijanga). This matched the national distribution and was representative of Bujenje County of Western Uganda [8]. Only the youngest child in the household was included in the study and in case of twins in the household, both were included for cultural reasons. Each household was visited twice over a period of 1 month and only children from households with mothers/caretakers present were recruited.

\section{Data collection and management}

Self-administered questionnaires were used to collect data on socioeconomic and demographic characteristics of households as well as morbidity status and dietary practices of children.

Anthropometric measurements were taken using calibrated equipment and standardized techniques [16]. Standing height/ length was taken using Short's Height Measuring Board (Short Productions, Woonsocket, RI) and recorded to the nearest $0.1 \mathrm{~cm}$. Body weight was taken using light weight SECA mother-infant scales with a digital screen that were designed and manufactured under the guidance of UNICEF. Mid Upper Arm Circumference (MUAC) was measured basing on WHO guidelines and recorded to the nearest $0.1 \mathrm{~cm}$ [17]. All measurements were taken in duplicate with the children in light clothing and without shoes. Each measurement was taken by the same person to eliminate inter examiner error. 


\section{Statistical analysis}

Data was entered, cleaned and analyzed using SPSS (Statistical Package for Social Scientists) version 20.0 for windows. Nutritional status indices for Heightfor-Age (HAZ), Weight-for-Age (WAZ), Weight-for-Height (WHZ) and Mid Upper Arm Circumference (MUAC) were calculated using ENA for SMART 2010 software and interpreted using WHO's 2006 reference standards. The nutrient intake derived from the porridges was determined basing on laboratory results from our previous study [18] and compared with World Health Organisation's (WHO) recommendations [19]. The Body Mass Index (BMI) of mothers was categorised basing on WHO recommendations [6] as follows;

\begin{tabular}{ll} 
Value & Classification \\
\hline$<18.5$ & Underweight \\
$18.5-24.9$. & Normal \\
$25-29.9$ & Overweight \\
30 and above & Obesity
\end{tabular}

Descriptive statistics were compiled. Pearson's Chi-square tests using Cross tabulations were done to establish the influence of demographic and socioeconomic characteristics, and morbidity patterns on children's nutritional status. Correlation between nutritional status and amounts of millet porridges consumed by children was established using Pearson's correlation coefficient analysis. A $p$-value of $<0.05$ was accepted as indicating statistical significance.

\section{Ethical approval}

This study was reviewed by The Aids Support Organisation (TASO) internal review board (TASOIRC/ 029/13-UG-IRC-009) and approved by the Uganda National Council of Science and Technology (HS 1315). Verbal and written consent were obtained from the parents of the study children.

\section{Results}

Socioeconomic and demographic characteristics of the population studied

Data was collected from 636 children and their mothers/ caretakers. The biggest population of sampled children (58.6\%) were from Bwijanga Sub County (Table 1). Nearly half $(46.4 \%)$ of all the households had a total household income ranging from $\$ 10-14.9$ per year. We could not collect data on household income for 58 households because they were not willing to disclose their income. More than half of the children (54.4\%) were males and $41.7 \%$ of the children studied were aged 12-23 months. Slightly more than half $(57.9 \%)$ of the children were either first or second born. We were not able to establish the
Table 1 Demographic and socioeconomic characteristics of the population studied

\begin{tabular}{|c|c|c|}
\hline Parameter & Number & Percent \\
\hline \multicolumn{3}{|l|}{ Sub County } \\
\hline Bwijanga & 263 & 58.6 \\
\hline Budongo & 373 & 41.4 \\
\hline \multicolumn{3}{|c|}{ Household income per year (\$) } \\
\hline $10-14.9$ & 295 & 46.4 \\
\hline $15-19.9$ & 178 & 28.0 \\
\hline $20-24.9$ & 80 & 12.6 \\
\hline $25-30$ & 25 & 13.0 \\
\hline \multicolumn{3}{|l|}{ Sex of studied children } \\
\hline Male & 346 & 54.4 \\
\hline Female & 290 & 45.6 \\
\hline \multicolumn{3}{|l|}{ Age of children (months) } \\
\hline $7-8$ & 60 & 9.4 \\
\hline $9-11$ & 65 & 10.2 \\
\hline $12-23$ & 265 & 41.7 \\
\hline $24-36$ & 246 & 38.7 \\
\hline \multicolumn{3}{|l|}{ Birth order } \\
\hline $1-2$ & 367 & 57.9 \\
\hline $3-4$ & 162 & 25.6 \\
\hline$>4$ & 105 & 16.5 \\
\hline \multicolumn{3}{|c|}{ Caretaker of the index child } \\
\hline Mother & 584 & 91.8 \\
\hline Grandmother & 31 & 4.9 \\
\hline Aunt & 21 & 3.3 \\
\hline \multicolumn{3}{|l|}{ Mother's marital status } \\
\hline Not married & 109 & 18.7 \\
\hline Married & 475 & 81.3 \\
\hline \multicolumn{3}{|l|}{ Mother's education level } \\
\hline Informal education & 53 & 8.3 \\
\hline Primary & 460 & 72.4 \\
\hline Secondary & 123 & 19.3 \\
\hline \multicolumn{3}{|c|}{ Mothers Body Mass Index (BMI) } \\
\hline < 18.5 (Underweight) & 163 & 27.9 \\
\hline 18.5-24.9 (Normal) & 370 & 63.4 \\
\hline 25-29 (Overweight) & 51 & 8.7 \\
\hline
\end{tabular}

birth order of two of the study children because their caretakers lacked this information. Most of the children studied $(91.8 \%)$ were taken care of by their mothers. Almost $81 \%$ of the mothers were married and $72.4 \%$ had completed primary education.

\section{Nutritional status of the studied children}

Table 2 shows the nutritional status of children in Bujenje County. Stunting, underweight, wasting and 
Table 2 Prevalence of stunting, underweight and wasting in Bujenje County

\begin{tabular}{|c|c|c|c|c|}
\hline \multirow[t]{2}{*}{ Nutritional status } & \multicolumn{2}{|c|}{ Sub Counties } & \multirow{2}{*}{$\begin{array}{l}\text { Bujenje } \\
\text { County } \\
\text { n (\%) }\end{array}$} & \multirow{2}{*}{$\begin{array}{l}p \text { - } \\
\text { value }\end{array}$} \\
\hline & $\begin{array}{l}\text { Budongo } \\
\mathrm{n}(\%)\end{array}$ & $\begin{array}{l}\text { Bwijanga } \\
n(\%)\end{array}$ & & \\
\hline Stunting (<-2 z-scores) & $71(27.1)$ & $123(33.0)$ & $194(30.5)$ & 0.063 \\
\hline Moderate $>-3$ to $<-2 z$-scores & $55(20.9)$ & $91(24.4)$ & $146(23.0)$ & \\
\hline Severe $<-3$ z-scores & $16(6.1)$ & $32(8.6)$ & $48(7.5)$ & \\
\hline Underweight (<-2 z-scores) & $39(14.8)$ & $35(9.4)$ & $74(11.6)$ & 0.044 \\
\hline Moderate $>-3$ to $<-2$ z-scores & $30(11.4)$ & $31(8.3)$ & $61(9.6)$ & \\
\hline Severe $<-3$ z-scores & $9(3.4)$ & $4(1.1)$ & $13(2.0)$ & \\
\hline Wasting (<-2 z-scores) & $29(11)$ & $18(4.8)$ & $47(7.4)$ & 0.005 \\
\hline Moderate ( $>-3$ to $<-2$ z-scores) & $24(9.1)$ & $14(3.8)$ & $38(6.0)$ & \\
\hline Severe (<-3 z-scores) & $5(1.9)$ & $4(1.1)$ & $9(1.4)$ & \\
\hline \multicolumn{5}{|l|}{ MUAC } \\
\hline Severe $(<11.5)$ & $50(1.9)$ & $4(1.1)$ & $9(1.4)$ & \\
\hline Moderate (11.5-12.4) & $19(7.2)$ & $16(4.3)$ & $35(5.5)$ & 0.030 \\
\hline At risk (12.5-13.5) & $29(11.0)$ & $23(6.2)$ & $52(8.2)$ & \\
\hline
\end{tabular}

under nutrition by MUAC among children in the study area were $30.5,11.6,7.4$ and $6.9 \%$ respectively. Stunting was higher in Bwijanga Sub County (33\%) compared with Budongo Sub County (27.1\%) but the difference was not significant. Underweight was significantly higher in Budongo Sub County (14.8\%) than Bwijanga Sub County $(9.4 \%)$ at $p=0.044$. Similarly, wasting was significantly higher in Budongo Sub County (11\%) than Bwijanga Sub County (4.8\%) at $p=0.005$. Under nutrition as determined by MUAC, was also significantly higher in Budongo Sub County (9.1\%) than Bwijanga Sub County $(5.4 \%)$ at $p=0.030$. Stunting and underweight significantly increased after 12 months but reduced later at 24-36 months ( $p=0.005$ and 0.020 respectively). Males were significantly more stunted and underweight than females at $p<0.001$. The percentage of malnourished children (stunting, underweight and wasting) reduced with increasing household size. The significant reduction was observed in underweight at $p=0.042$ (Table 3).

Table 4 shows that majority of the stunted and underweight children had diarrhea 2 weeks prior to the study and children with diarrhea were 1.4 and 2.0 times likely to become stunted and underweight at $p=0.025$ and $p=0.007$ respectively.

\section{Nutrient intake from millet porridges}

The mean frequency of feeding children on millet porridges varied from $1.91 \pm 0.91$ to $3.02 \pm 0.05$ meals per day. The amount of porridges consumed per day varied from $412.65 \pm 3.67$ to $906 \pm 9.80 \mathrm{ml}$. The porridges were deficient of vitamin A and they covered less than $60 \%$ of the recommended energy, protein, iron and zinc intake (Table 5). There was a significant association between the amount of millet porridge consumed by children per day and children's Height-for-Age, Weight-for-Height Z scores $(r=-0.20, p<0.001$ and $r=0.14, p<0.001)$ respectively.

\section{Knowledge and healthcare practices for children with diarrhea}

More than half of the mothers/caretakers (74.2\%) had knowledge about oral rehydration salts and $28.5 \%$ of these reported giving Oral Rehydration Salts to their children. Only $69 \%$ of the children with diarrhea visited a health facility for treatment. Recommended amounts of food and fluids for children with diarrhea were received by 15.2 and $47.5 \%$ respectively as shown in Table 6.

\section{Discussion}

Demographic and socioeconomic characteristics of the studied population

Majority of households in Bujenje County lived on less than $\$ 2$ per day. This reflects an extreme state of poverty which could negatively influence the nutrition status of children. Child malnutrition in Uganda, just like in most developing countries is strongly associated with poverty $[2,5,20,21]$. Many mothers were taking care of their own children instead of employing caretakers possibly because this is a rural based community. Such a good practice could enhance proper care which is a key aspect in child growth and development [22]. Reported low levels of education among majority of mothers limit utilisation of the already limited resources to improve children's nutritional status especially given the fact that more than half of the children were either first or second born, probably mothers lacked experience in childcare [22]. Majority of the mothers of the studied children had a 
Table 3 Nutritional status according to child characteristics and household size

\begin{tabular}{|c|c|c|c|c|c|c|}
\hline \multirow[t]{2}{*}{ Variable } & \multicolumn{2}{|l|}{ Stunting } & \multicolumn{2}{|l|}{ Underweight } & \multicolumn{2}{|l|}{ Wasting } \\
\hline & $\%$ prevalence & $\begin{array}{l}\text { Mean } \\
\text { HAZ }\end{array}$ & $\%$ prevalence & $\begin{array}{l}\text { Mean } \\
\text { WAZ }\end{array}$ & $\begin{array}{l}\% \\
\text { prevalence }\end{array}$ & $\begin{array}{l}\text { Mean } \\
\text { WHZ }\end{array}$ \\
\hline \multicolumn{7}{|c|}{ Age (months) } \\
\hline $7-8$ & 2.5 & $2.67 \pm 0.78$ & 2.0 & $2.75 \pm 0.07$ & 0.9 & $2.90 \pm 0.05$ \\
\hline $9-11$ & 1.2 & $2.85 \pm 0.05$ & 0.9 & $2.89 \pm 0.04$ & 0.6 & $2.94 \pm 0.03$ \\
\hline $12-23$ & 14.5 & $2.56 \pm 0.04$ & 5.5 & $2.84 \pm 0.03$ & 3.9 & $2.89 \pm 0.02$ \\
\hline $24-36$ & 12.3 & $2.61 \pm 0.04$ & 3.2 & $2.89 \pm 0.03$ & 2.0 & $2.93 \pm 0.02$ \\
\hline$p$-value & 0.005 & 0.009 & 0.020 & 0.059 & 0.329 & 0.490 \\
\hline \multicolumn{7}{|l|}{ Sex } \\
\hline Male & 10.5 & $2.54 \pm 0.04$ & 3.1 & $2.81 \pm 0.03$ & 4.3 & $2.91 \pm 0.02$ \\
\hline Female & 20.0 & $2.71 \pm 0.043$ & 8.5 & $2.92 \pm 0.02$ & 3.1 & $2.91 \pm 0.02$ \\
\hline$p$-value & 0.001 & 0.017 & 0.001 & 0.001 & 0.760 & 0.910 \\
\hline \multicolumn{7}{|c|}{ Household size } \\
\hline$<5$ & 16.5 & $2.56 \pm 0.04$ & 6.8 & $2.83 \pm 0.03$ & 4.7 & $2.89 \pm 0.02$ \\
\hline $5-7$ & 9.4 & $2.70 \pm 0.04$ & 2.8 & $2.91 \pm 0.02$ & 1.9 & $2.94 \pm 0.02$ \\
\hline Above 7 & 4.6 & $2.62 \pm 0.06$ & 2.0 & $2.85 \pm 0.04$ & 0.8 & $2.93 \pm 0.03$ \\
\hline$p$-value & 0.084 & 0.040 & 0.042 & 0.020 & 0.089 & 0.170 \\
\hline
\end{tabular}

normal Body Mass Index (BMI). This is very crucial if mothers are to care for the health and nutritional needs of their children well. Breast milk production has been reported to be low among malnourished mothers and association of BMI with poor child nutrition status has also been reported [22].

\section{Prevalence of stunting, underweight and wasting among the studied children}

Stunting estimates were higher than the global percentages of $25 \%$ while underweight and wasting estimates were less than the global estimates of 15 and $8 \%$ respectively [23]. Stunting, underweight and wasting levels were comparable to national figures of 29,11 and $4 \%$ respectively and those of Bunyoro sub region (34.5, 9.1 and 3.8\% respectively) of children below 5 years. The levels were also close to 26.6, 13.9 and $10.1 \%$ stunting, underweight and wasting respectively reported among children below 5 years in

Table 4 Nutritional status basing on prevalence of diarrhea in the previous 2 weeks

\begin{tabular}{llll}
\hline \multirow{2}{*}{$\begin{array}{l}\text { Nutritional } \\
\text { status }\end{array}$} & \multicolumn{2}{l}{ Diarrhea in the last 2 weeks } & OR $(95 \% \mathrm{Cl})$ \\
\cline { 2 - 3 } & $\begin{array}{l}\text { Yes } \\
\text { (n) \% }\end{array}$ & $\begin{array}{l}\text { No } \\
\text { (n) \% }\end{array}$ & \\
\hline Stunted & $124(63.9)$ & $70(36.1)$ & $1.437(1.015-2.035)$, \\
Normal & $244(55.2)$ & $198(44.8)$ & $p=0.025$ \\
Underweight & $53(71.6)$ & $21(28.4)$ & $1.979(1.162-3.369)$, \\
Normal & $315(56.0)$ & $247(44.0)$ & $p=0.007$ \\
Wasted & $25(53.2)$ & $22(46.8)$ & $0.815(0.449-1.479)$, \\
Normal & $343(58.2)$ & $246(41.8)$ & $p=0.300$ \\
\hline
\end{tabular}

cassava consuming communities of Nambale, Busia of Western Kenya [13]. According to the World Health Organisation classification of children's nutritional status, such percentages of stunted and underweight children reflect serious malnutrition conditions [3]. The prevalence of wasting among these children is ranked as that which demands for interventions [17]. Stunting represents failure of children to receive adequate nutrition over a long period of time and is affected by recurrent and chronic illnesses [3]. Underweight takes into account both chronic and acute under nutrition and it is an overall indicator of a population's nutritional health [6]. Wasting represents failure of children to receive adequate nutrition in the period immediately preceding the study and this was due to inadequate food intake or a recent episode of diarrhoea or both. Acutely malnourished children who are not immediately treated are likely to develop clinical conditions requiring hospitalisation. Such conditions can cause irreversible damage to mental development [3]. Many health centres tend to be crowded with severely malnourished children and this presents a heavy cost to governments and individuals in the process of treating complications associated with severe acute malnutrition [3].

Stunting and wasting levels were significantly higher in males than females just like in the national reports [6]. This has been reported by other studies and is quite common in the absence of discriminatory measures, but its mechanism is not clear $[24,25]$. However it has also been observed that most girl children are trained to be close to their mothers' right from the early stages of life 
Table 5 Nutrient intake from millet porridges

\begin{tabular}{|c|c|c|c|c|}
\hline Variable & $7-8$ months & 9-11 months & $12-23$ months & 24-36 months \\
\hline Frequency of feeding & $1.91 \pm 0.19$ & $2.13 \pm 0.15$ & $2.80 \pm 0.07$ & $3.02 \pm 0.05$ \\
\hline Amount of porridges/day (millilitres) & $412.65 \pm 3.67$ & $558.12 \pm 13.69$ & $841.01 \pm 7.94$ & $906.32 \pm 9.80$ \\
\hline \multicolumn{5}{|l|}{ aEnergy } \\
\hline Recommended intake & $269 \mathrm{kcal}$ & $451 \mathrm{kcal}$ & 746 k cal & $1150 \mathrm{kcal}$ \\
\hline Total intake & $69.5 \mathrm{kcal}$ & $156.1 \mathrm{kcal}$ & 236.6 k cal & 196.4 k cal \\
\hline$\%$ RNI covered & 26 & 35 & 32 & 17 \\
\hline \multicolumn{5}{|l|}{ Protein intake } \\
\hline Recommended intake & $9.1 \mathrm{~g}$ & $9.6 \mathrm{~g}$ & $10.9 \mathrm{~g}$ & $13 \mathrm{~g}$ \\
\hline Total intake & $1.6 \mathrm{~g}$ & $3.7 \mathrm{~g}$ & $5.6 \mathrm{~g}$ & $4.7 \mathrm{~g}$ \\
\hline$\% \mathrm{RNI}$ covered & 18 & 39 & 51 & 36 \\
\hline \multicolumn{5}{|l|}{ Vitamin A intake (RE) } \\
\hline Recommended intake & $250 \mu \mathrm{g}$ & $300 \mu \mathrm{g}$ & $300 \mu \mathrm{g}$ & $300 \mu \mathrm{g}$ \\
\hline Total intake & $0 \mu \mathrm{g}$ & $0 \mu \mathrm{g}$ & $0 \mu \mathrm{g}$ & $0 \mu \mathrm{g}$ \\
\hline$\% \mathrm{RNI}$ & 0 & 0 & 0 & 0 \\
\hline \multicolumn{5}{|l|}{ Iron intake } \\
\hline Recommended intake & $11 \mathrm{mg}$ & $11 \mathrm{mg}$ & $11 \mathrm{mg}$ & $11 \mathrm{mg}$ \\
\hline Total intake & $1.8 \mathrm{mg}$ & $4.0 \mathrm{mg}$ & $6.0 \mathrm{mg}$ & $5.0 \mathrm{mg}$ \\
\hline$\%$ RNI & 16 & 36 & 55 & 45 \\
\hline \multicolumn{5}{|l|}{ Zinc intake } \\
\hline Recommended intake & $2.8 \mathrm{mg}$ & $2.8 \mathrm{mg}$ & $2.8 \mathrm{mg}$ & $3 \mathrm{mg}$ \\
\hline Total intake & $0.4 \mathrm{mg}$ & $0.9 \mathrm{mg}$ & $1.3 \mathrm{mg}$ & $1.1 \mathrm{mg}$ \\
\hline$\% \mathrm{RNI}$ & 14 & 32 & 46 & 37 \\
\hline
\end{tabular}

${ }^{a}$ Energy required from complementary foods assuming average amount of breast milk. Iron: Assuming medium iron bioavailability (10\%). Zinc: Assuming moderate bioavailability (30\%). References for Recommended Nutrient Intake (RNI): World Health Organisation Recommendation [18]

for cultural reasons, this closeness could attract some privileges like food, especially when there is shortage of food.

The proportion of stunted and underweight children was highest between the ages of 12-23 months which was the weaning period for most of the studied children. This has been reported to be the common age for stunting in most communities with poor quality complementary foods [2]. Weaning children with less nutritious foods affects them since this age group is characterised by high nutrient requirements and limited gastric capacity [26]. The situation is even made worse when infections set in [10]. Increase of stunting with age is consistent with other studies [27] and might also be due to reduced care as some mothers tend to become very busy with economic activities outside the household as children are weaned [28]. The percentage of children who met the recommended nutrient intake (RNI) tended to decrease with age due to increased nutrient requirements as children grew. Most mothers were still relying heavily on porridges without introducing other foods to children and this could have negatively affected the children.

\section{Factors influencing the nutritional status of the studied children}

Our previous findings among children aged 7-24 months in this area showed that majority of these children had inadequate nutrient intake [10]. Children were fed on bulky plant foods with minimal animal products, fruits and vegetables, contrary to World Health Organisation's recommendations for complementary feeding [10]. Millet porridges formed the bulk of these children's feeding and were very thin contributing less than $60 \%$ of the daily recommended nutrient intake for energy, protein, iron and zinc. The fact that millet porridges had no vitamin A calls for interventions to provide vitamin $\mathrm{A}$ in supplements form in order for children to grow as required. Weight-for Height Z scores (WHZ) were positively associated with the amounts of millet porridges taken by children meaning that these porridges are still key players in improving the nutritional status of children in this community. Millet porridges have been reported by some scholars as the most nutritious food among cereals [11]. However there is need to improve the nutritive value of millet porridges if under nutrition among children living in these places is to be addressed. Height-for-Age $\mathrm{Z}$ scores were negatively 
Table 6 Knowledge and healthcare practices for children with diarrhoea

\begin{tabular}{lll}
\hline Variable & $N=368$ & $\%=100$ \\
\hline Knowledge of Oral Rehydration Salts (ORS) & & 25.8 \\
No & 95 & 74.2 \\
Yes & 273 & \\
Used ORS for the child with diarrhoea & & 28.5 \\
Yes & 263 & 71.5 \\
No & 105 & \\
Source of treatment for diarrhoea & & 69.0 \\
$\quad$ Visited a health facility & 254 & 2.2 \\
$\quad$ Used herbs & 8 & 28.0 \\
Self medication & 103 & 0.8 \\
Faith healing & 3 & \\
Amount of food offered to a child & & 72.6 \\
with diarrhoea & & 15.2 \\
$\quad$ Same as usual & 267 & 12.2 \\
More than usual (Recommended) & 56 & \\
Less than usual & 45 & 52.2 \\
Amount of fluids offered to a child & & 47.5 \\
with diarrhoea & & \\
Same as usual & 192 & \\
More than usual (Recommended) & 175 & \\
Less than usual & 1 & \\
\hline
\end{tabular}

associated with the amount of porridges taken. This was because majority of stunted children were $12-36$ months old, where in addition to porridges, mothers were supposed to give other nutritious solid foods. Majority of stunted and underweight children had diarrhoea in the 2 weeks preceding the study and they were more likely to be stunted with low weight. Although WHO recommends increased intake of both food and fluids when children have diarrhoea, many mothers did the contrary perhaps because of lack of knowledge. Uganda Demographic and Health Surveys have also reported feeding practices for children with diarrhoea as being contrary to World Health Organisation's recommendations. Infections affect dietary intake and utilization and this has a negative effect on the nutritional status of children [22]. After an acute infection, weight gain may be relatively rapid but linear growth is slower, and where infections occur frequently, linear growth recovery may never occur resulting in persistent stunting [3]. In Uganda diarrhoea is a common cause of under nutrition among children and accounts for about 40-50\% lower intake for energy and protein among children [3]. We have previously reported that most mothers kept millet porridges for long periods under unhygienic conditions before feeding the children, such a practice could easily attract infections [10]. Many mothers were also involved in digging or providing casual labour to sugar cane plantations where they carry their children along. Such practices could easily result in children picking infections as their immunity is not yet fully developed [3].

Households with few members had majority of their children underweight especially those households comprising mainly of children. This could be due to the dependency burden since majority of the study population were peasant farmers. It also reflects the aspect of proper childcare which is very important in the early stages of growth and development. A study on the nutritional status of children in Gabon also showed better Weightfor-Height $\mathrm{Z}$ scores among children from households with many members [29]. Since young children have limited gastric capacity, there is need for feeding them frequently and this can only be possible with availability of parent/caretaker. Essential practices like being hygienic, visiting a health facility/provider when sick, giving vitamin A supplements as recommended and de-worming can only be possible if caretakers are available.

Majority of mothers though knowledgeable about Oral Rehydration Salts (ORS) had poor feeding practices during diarrhoea. This could have been responsible for the high wasting levels compared to national figures especially since the period data was collected was a rainy season when infections are high. Caretakers need to be educated on the recommended healthcare practices during diarrhoea. There is need to get an affordable and sustainable solution to the poor healthcare and feeding practices in these rural communities if good nutritional status is to be achieved among children. This perhaps can be done by improving the value of millet porridge, since it is locally available and affordable by most households.

\section{Conclusions}

The stunting, underweight and wasting levels among children from millet consuming communities in Masindi District are slightly higher than the national figures. This was attributed to high incidences of diarrhoea and inadequate nutrient intake from millet porridges especially for children aged $12-36$ months. Association of millet porridges with improved Weight-for-Height Z scores in children implies that they have the potential of improving the nutritional status of children if their nutritional value is improved. However, there is also need for timely introduction of solid foods and addressing aspects of poor healthcare practices.

\section{Abbreviations}

BMI: Body Mass Index; Cl: Confidence intervention; ENA: Emergency nutrition assessment; HAZ: Height-for-Age Z score; OR: Odds ratio; RNI: Recommended nutrient intake; SD: Standard deviation; SPSS: Statistical Package for Social Scientists; TASO: The Aids Support Organisation; UNICEF: United Nations' Children Fund; WAZ: Weight-for-Age Z score; WHO: World Health

Organisation; WHZ: Weight-for-Height Z score 


\section{Acknowledgements}

The authors would like to thank the parents/caretakers of the study children for willingly participating in this study and the field assistants who diligently collected the data. Dr. Grace Muhoozi is acknowledged for revising the manuscript for both grammatical and intellectual content.

\section{Funding}

Kyambogo University found in Uganda funded this project. However it had no role in the design of the study, collection, analysis, and interpretation of data and in the writing of the manuscript.

\section{Availability of data and materials}

The datasets used and/or analysed during the current study are available from the corresponding author on reasonable request.

\section{Authors' contributions}

This was an award research for EBI. The designing, analysis and interpretation of data involved EBI, SKM and EK. EBI collected the data and drafted the manuscript which was revised by both SKM and EK for intellectual content. All authors read and approved the final manuscript.

\section{Authors' information}

Not available

\section{Ethics approval and consent to participate}

The design and ethics of the study were reviewed and cleared by The Aids Support Organisation (TASO) internal review board (TASOIRC/029/13-UG-IRC-009), and then approved by the Uganda National Council of Science and Technology (HS 1315). Verbal and written consent from the mothers/caregivers of the study children was given by signing a form.

\section{Consent for publication}

Not applicable.

\section{Competing interests}

The authors declare that they have no competing interests.

\section{Publisher's Note}

Springer Nature remains neutral with regard to jurisdictional claims in published maps and institutional affiliations.

Received: 2 January 2018 Accepted: 29 January 2019

Published online: 11 February 2019

\section{References}

1. Kabir I, et al. Determinants of inappropriate complementary feeding practices in infant and young children in Bangladesh: secondary data analysis of demographic health survey 2007. Matern Child Nutr. 2012;8(s1):11-27.

2. Victora $\mathrm{CG}$, et al. Worldwide timing of growth faltering: revisiting implications for interventions. Pediatrics. 2010;125:e473 p. peds. 2009-1519.

3. FANTA-2. The Analysis of the Nutrition Situation in Uganda. Food and Nutrition Technical Assistance II Project (FANTA-2). Washington, DC: AED; 2010.

4. UNICEF, WHO, and W. Bank. UNICEF-WHO-Word Bank Joint Malnutrition Estimates. Geneva: The World Bank, Washington, DC; 2012.

5. UBOS and ICF. Uganda Demographic and Health Survey 2016: Key Indicators Report. Kampala: UBOS and ICF, Rockville: UBOS; 2017.

6. UBOS and ICF. Uganda Demographic and Health Survey, 2011. Kampala and Calverton: UBOS and ICF International Inc; 2012.

7. UBOS and ICF. Uganda Demographic and Health Survey. Calverton: Entebbe and ORC macro; 2001

8. Masindi DDHS. Masindi District Health Services Annual Report 2006. Masindi; 2007.

9. Harvey, Rambeloson, Omar. The 2008 Uganda Food Consumption Survey: Determining the Dietary Patterns of Ugandan Women and Children. Washington D.C: A2Z: The USAID Micronutrient and Child Blindness Project, AED; 2010.

10. Isingoma BE, et al. Socioeconomic and Demographic Factors Influencing Feeding Practices, Morbidity Status, and Dietary Intakes of Children Aged 724 Months in Rural Uganda. Ecol Food Nutr. 2016;56(1):1-16.

11. Singh P, Raghuvanshi RS. Finger millet for food and nutritional security. Afr J Food Sci. 2012;6(4):77-84.
12. Bachar $\mathrm{K}$, et al. Fiber content and mineral composition of the finger millet of the oasis of Gabes Tunisia. J Agric Sci. 2013;5(2):p219.

13. Nungo RA, Okoth MW, Mbugua SK. Nutrition status of children under-five years in cassava consuming communities in Nambale, Busia of Western Kenya. Food Nutr Sci. 2012;3:796-801.

14. Onyango $C$, et al. Digestibility and antinutrient properties of acidified and extruded maize-finger millet blend in the production of uji. 38, 697-707. LWT Food Sci Technol. 2005;38:697-707.

15. Israel D. Determining sample size. Gainesville: IFAS, University of Florida; 2003.

16. Lohman T, Roche A, Martorell R, editors. Anthropometric standardisation. Reference manual. Champagne: Human Kinetics Books; 1998.

17. WHO. WHO Global Database on Child Growth and Malnutrition. Geneva: World Health Organisation Document No.WHO/NUT/97.4; 1997.

18. Isingoma BE, et al. Improving the nutritional value of traditional finger millet porridges for children aged 7-24 months in Bujenje County of Western Uganda. Afr J Food Sci. 2015;9(8):426-36.

19. Dewey K, Brown K. Update on technical issues concerning complementary feeding of young children in developing countries and implications for interventional programs. Food Nutr Bull. in press;2002.

20. Hossain MI, Wahed MA, Ahmed S. Increased food intake after the addition of amylase-rich flour to supplementary food for malnourished children in rural communities of Bangladesh. Food Nutr Bull. 2005;26(4):323.

21. Bryce J, et al. WHO estimates of the causes of death in children. Lancet. 2005;365:1147-57.

22. Girma W, Ganebo T. Determinants of Nutritional status of women and children in Ethiopia. Calverton: ORC Macro; 2002.

23. de onis M, Brown D, Blossner M, Borghi E. UNICEF. WHO/World Bank (2012) levels and trends in child malnutrition: UNICEF-WHO-the World Bank joint child malnutrition estimates. New York: United Nations Children's Fund, World Health Organization and World Bank; 2012.

24. Jooste PM, et al. Nutritional status of rural children in the lesotho Highlands. East Afr Med J. 1998:74:680-9.

25. Ngare D, Muttunga J. Prevalence of malnutrition in Kenya. East Afr Med J. 1999:76:376-80.

26. Daelmans B, Martines J, Saadeh R. Special issue based on a World Health Organisation Expert Consultation on complementary feeding. Food Nutr Bull. 2003;24(1):1-139.

27. Sapkota V, Gurung C. Prevalence of underweight, stunting and wasting in underfive children. J Nepal Health Res Counc. 2009;7(15):120-6.

28. Ricci J, et al. The effect of maternal time use on children's well-being. Soc Sci Med. 1996;42:651-9.

29. Blaney S, Beaudry M, Latham M. Contribution of natural resources to nutritional status in a protected area of Gabon. Food Nutr Bull. 2009;30(1):49-60.

Ready to submit your research? Choose BMC and benefit from:

- fast, convenient online submission

- thorough peer review by experienced researchers in your field

- rapid publication on acceptance

- support for research data, including large and complex data types

- gold Open Access which fosters wider collaboration and increased citations

- maximum visibility for your research: over $100 \mathrm{M}$ website views per year

At $\mathrm{BMC}$, research is always in progress.

Learn more biomedcentral.com/submissions 